\title{
Statutory General Anti-Abuse Rule in the Slovak Tax Code: Some Expectations and the Reality of Its Implementation ?
}

\author{
František Bonk ${ }^{*}$, Karin Cakoci* ${ }^{* *}$
}

\begin{abstract}
* JUDr. František Bonk, PhD, Research Associate at the Department of Financial Law, Tax Law and Economy at the Faculty of Law, Pavol Jozef Šafarik University in Košice. (e-mail: frantisek.bonk@ upjs.sk)

** Doc. JUDr. Karin Cakoci, PhD, Associate Professor at the Department of Financial Law, Tax Law and Economy at the Faculty of Law, Pavol Jozef Šafarik University in Košice. (e-mail: karin. cakoci@upjs.sk)
\end{abstract}

\begin{abstract}
This article aims towards an analysis of the Slovak Statutory General Anti-Abuse Rule (henceforth GAAR) which entered into force under the initiatives of the EU and OECD on 1 January 2014. The article provides an analysis of the particular construction elements of the implemented GAAR with respect to the European Court of Justice (henceforth ECJ) case law and GAAR legislative practice at EU level, which is seemingly, with regard to the Anti-Tax Avoidance Directive GAAR, unstoppable.
\end{abstract}

Keywords: statutory general anti-abuse rule; tax code in Slovakia; counteracting tax avoidance; implementation of EU initiatives

\section{Introduction}

In recent years, the abuse of tax law has become a topical issue in the European Union. This is clearly demonstrated by the case law of the ECJ, the significance of which has contributed to the creation of the principle of prohibition of the abuse of tax law, and it is convincingly justified by the papers in tax law science. ${ }^{2}$ ECJ established the prohibition of the abuse of tax law in both indirect and direct taxation areas by Halifax and Cadbury Schweppes rulings. ${ }^{3}$ Some years later, a strong legislative initiative in incorporating statutory GAARs began at EU level. ${ }^{4}$ Tax jurisdictions of the Central and Eastern European Countries (henceforth CEE countries) were understandably a rather obvious target: most of them had not contained statutory GAAR provisions in their domestic tax systems before. Neither their judicial GAARs - the prohibition of abuse of tax law doctrines had been developed. Or, at the same time, under the judicial development, the domestic doctrine had to face ECJ's developing prohibition of abuse doctrine in the tax law area.

EU statutory GAARs have the refore played "a model role" by their application in domestic tax systems. However, the way of implementation with regard to the Slovak tax 
law is not that obvious, as it will be shown later on. Implementing statutory GAAR without previous experience is rather a serious issue and authors will try to analyse if the Slovak GAAR had been implemented correctly (if not, what would be the way of its implementation). Due to the limited scope of the article, the emphasis will not be fully given to national judicial doctrine of prohibition of tax law abuse. Under the ECJ's case law development, particular construction elements of statutory GAAR will be analysed in detail.

\section{2. "EU GAAR" as an Implementation Model}

GAAR as a rule devoted to prevention of tax evasions and tax avoidance has been in force in the Slovak Tax Code since 1 January 2014, following international initiatives in tax evasions and tax frauds prevention. Under the Explanatory report to Act no. 435/2013 Coll., the reasons for amendment are represented by:

- measures proposed by the Analysis of the payments for goods, services and other forms of payments made by taxpayers for the benefit of persons established in noncooperative and off-shore jurisdictions, as well as

- Commission recommendation of 6 December 2012 on aggressive tax planning (C(2012) 8806 final). ${ }^{5}$

Especially the wording of the "EU GAAR" that is included in the Commission's recommendation proved to have a strong influence on the implementation of statutory GAARs within the CEE region. By the wording of legally non-binding recommendation the Slovak law maker had rather promptly transposed the new clause into the Slovak Tax Code. This article is not a comprehensive analysis of the whole abuse of tax law doctrine; attention is devoted only to the analysis of the criteria which had been established by the ECJ taking into account requirements of the statutory GAAR provisions at EU level.

It seems to be clear that "EU GAAR" incorporated in the text of recommendation codifies the formerly developed ECJ doctrine on the prohibition of abuse of tax law. ${ }^{6}$ This has already been established in Emsland-Stärke - the case dealing with the refund of agricultural levies - where ECJ for the first time identified abuse of law under a twofold test of objective and subjective element of abuse. ${ }^{7}$ The case became enormously influential for the next development, waiting however until 2006 when abuse of tax law in both areas of indirect taxes (Halifax) ${ }^{8}$ and direct taxes (Cadbury Schweppes) 9 were confirmed. Landmark cases on the prohibition of the abuse of the tax law both followed a twofold test of objective and subjective element of the abuse of tax law settled by Emsland-Stärke. ${ }^{10}$ However, the concept of the prohibition of tax law abuse in the area of direct taxation established by Cadbury Schweppes developed a much narrower line, limiting the concept of abuse only to wholly artificial arrangements. ${ }^{11}$ The concept of "artificiality" at EU level, developed by the ECJ found its place in the wording of "EU GAAR" incorporated in the recommendation on aggressive tax planning. EU GAAR was introduced and proposed to be incorporated into national tax systems by means of the following clause: "An artificial 
arrangement or an artificial series of arrangements which has been put into place for the essential purpose of avoiding taxation and leads to a tax benefit shall be ignored. National authorities shall treat these arrangements for tax purposes by reference to their economic substance." ${ }^{12}$ Apart from that, the recommendation provides few paragraphs that explain concepts used in the wording of the clause - which constitutes particular elements of tax law abuse. Most importantly, after the implementation of the EU GAAR, objective and subjective elements of the Slovak GAAR in Tax Code will be analysed in the following text.

\section{Slovak GAAR in Tax Code and Its Application Elements}

As mentioned above, apart from the objective and subjective elements which represent the core testing of tax law abuse, other supplementary elements and application problems arise when analysing the wording of the national GAAR. At the very beginning, it is important to stress that GAAR is a new provision without previous experience in the application practice of the Slovak tax law, which is rather supplementing (not replacing) the formerly applied substance over the form rule that has been present and developed within the national case law. ${ }^{13}$

Statutory GAAR has recently became a part of our tax legislation by the following wording: "A legal action or other facts essential for identification, assessment or collection of a tax without an economic substance and resulting into a purpose-built tax avoidance or acquisition of such tax benefit to which the taxpayer would not be otherwise entitled or resulting into a purpose-built reduction in tax liability shall be disregarded within administration of taxes." With the next text, particular construction elements will be analysed with respect to the implemented clause.

When analysing Slovak GAAR in Tax Code, which had been implemented under the Commission's recommendation on aggressive tax planning, some differences are already present with regard to the application scope of the implemented provision. Contrary to the EU GAAR that had been adopted in order to counteract aggressive tax planning in the area of direct taxation, ${ }^{14}$ the scope of the implemented Slovak GAAR is broader and covers all taxes within our tax system - indirect taxes, direct taxes and local taxes. ${ }^{15}$ The issue of the application of GAAR with the other levies/fees that are present in our legal system ${ }^{16}$ has not been confirmed yet and is rather the oretical, but in our view it could not be fully excluded. GAAR had been implemented as a rule which is aimed at directing not only taxes, but also tax avoidance cases arising from the whole tax system.

When it comes to the scope of situations in which GAAR should find its application, Slovak GAAR refers to legal action or other facts, and it seems that the scope of situations which are mentioned by the EU GAAR overlaps it. However, a legal action or other facts seem to be, in the narrower sense, compared to the concept of arrangement which for the purposes of the recommendation means any transaction, scheme, action, operation, agreement, grant, understanding, promise, undertaking or event. An arrangement may comprise more than one step or any part of it. Even the fact that by the wording of recommendation the arrangement may comprise more than one step or might partly bring 
some chaos by interpreting national GAAR. What could be an important moment for the application of GAAR? The verbatim Interpretation of the wording of the Slovak GAAR, the provision in itself shall be applied as soon as there is a legal action or some other fact that fulfils the statutory requirements of the applicable provision. This might rather be an expression of the need to introduce GAAR as an instrument which is applicable to all taxes, not only to tax avoidance schemes in the area of direct taxation that typically consists of more transactions, steps and operations in order to reach the final "tax arrangement". The terminology seems to be somehow confusing, nevertheless legal actions create arrangement(s). The issue is becoming interesting when it comes to the analysis of the objective and subjective testing of the Slovak statutory GAAR.

\subsection{The Objective Test of the Slovak GAAR}

The objective element of the abuse of tax law testing has been present already from Emsland-Stärke where ECJ held that despite formal observance of the conditions laid down by the Community rules, the purpose of those rules has not been achieved. ${ }^{17}$ Subsequently, the objective element has been confirmed under actions that resulted in obtaining tax benefit contrary to the purpose of those provisions in Halifax. ${ }^{18}$ Similarly, in order to find an abusive arrangement under Cadbury Schweppes ruling the objective pursued by the freedom of the establishment has not been achieved. ${ }^{19}$

The objective element is specified in the EU GAAR as well. Under paragraph 4.5 of the text of recommendation, "the purpose of an arrangement or series of arrangements consists in avoiding taxation where, (regardless of any subjective intentions of the taxpayer), it defeats the object, spirit and purpose of the tax provisions that would otherwise apply". It is the refore clear that the objective element is particularly emphasized by the wording of the above mentioned provision. But the requirement is given rather cumulatively and the objective element, interpreting the provision literally may be present only when the action of the taxpayer is of such kind that it defeats the object, spirit and purpose of the tax provisions that would otherwise apply. ${ }^{20}$ Interpretation problems are connected with the fact whether the object, spirit and purpose of the tax provision are of the same meaning or whether this should be examined separately. Lastly, EU GAAR is only a non-binding soft law and member states are free to implement the provision under their domestic interpretation standards, the refore a closer look at the wording of the implemented provision at the issue is needed.

Reading the wording of the Slovak GAAR in Tax Code the very first impression evokes that the objective element has to be deduced since it is not really clear from the wording of the clause. Where is the objective element in the Slovak GAAR? If we interpret the objective element in accordance with the ECJ case law and the EU GAAR, the objective element is actually not explicitly present within the wording of the clause. There is no explicit reference regarding the objective testing neither under the explanatory report with the amending law. ${ }^{21}$ The economic substance as an emphasized concept could not represent the objective test, it is rather a subjective criterion that is connected with the issue of artificiality. If we regard the objective test under EU law as a tool of testing 
the taxpayer's action against the object, purpose or the spirit of the particular tax provision (law), then such a test is simply not present within the wording of the Slovak GAAR. The provision in itself rather accounts for three statutory alternatives (besides the lack of the economic substance of the legal action or the other fact) if the abuse of tax law shall be confirmed. In order to apply GAAR, a legal action or other facts without an economic substance that fulfil one of the three alternatives have to be present. Either the $y$ have to result in:

- a purpose-built tax avoidance or

- an acquisition of such tax benefit to which the taxpayer would not be otherwise entitled or

- a purpose-built reduction in tax liability. ${ }^{22}$

An interesting point of these statutory alternatives in order to meet the legislative criteria of abuse is represented by the fact that only one of them mentions directly the obtainment of tax benefit as a substantial element when GAAR should be applied. Seemingly, it looks as if the words' purpose and result have been mixed in implementing the statutory GAAR. However, incorporating the test of "result" is not quite obvious. If there are more results of the particular transaction, which one should be decisive for the application of GAAR? Are non-tax results of importance interpreting the clause? The necessity of "result" in testing abuse brings only more chaos to the interpretation of the provision. After all, at the end of the day, in determining whether an arrangement or series of arrangements has led to a tax benefit, national authorities are invited to compare the amount of tax due by a taxpayer, having regard to those arrangement(s), with the amount that the same taxpayer would owe under the same circumstances in the absence of the arrangement $(s) .{ }^{23}$ This is in our view the way the result should be understood. However, the wording of GAAR evokes that apart from the unclear objective test, the subjective test plays an important role on the whole in identifying abuse.

\subsection{The Subjective Test in the Slovak GAAR}

Being of equal importance, the subjective test (starting already in Emsland-Stärke) represents besides the objective test the second criterion in identifying abuse. Reliability of the subjective testing had been partially disturbed by opinions of the general advocate in Halifax. ${ }^{24}$ Nevertheless, the ECJ had never resigned of finding both elements in order to identify abuse. Under the ECJ doctrine of prohibition of abuse, the subjective test is represented by the intention of the taxpayer to obtain tax benefit. ${ }^{25}$

Again, a closer look on how the subjective test is reflected by the wording of the Slovak GAAR is needed. Subjective testing is at EU level terminologically bounded by the concept of artificiality which has been brought to the wording of EU GAAR from the ECJ rulings. It was the ECJ in the first place, who mentioned the concept of (wholly) artificial arrangements, the combat which authorizes the restriction of the freedom of the establishment. ${ }^{26}$ The concept of artificiality lies apparently at the heart of the Commission's recommendation on aggressive tax planning. Under par. 4.4 of the recommendation, for 
the purposes of EU GAAR an arrangement or a series of arrangements are artificial when it lacks commercial substance. ${ }^{27}$ Such an explanation only replaces one ambiguous concept by another one and does not make it clear at all. ${ }^{28}$ An ambition to provide some examples of artificiality is rather positive; however, the shortlist might be only seen as a codification of few situations of abusive practices coming from the more developed national judicial doctrines of tax abuse, such as the German or British. A non-binding recommendation left the door open for transposing the subjective testing under the national standards and imaginations of the member states.

If we examine the wording of the Slovak GAAR in detail, there is nothing like an artificiality concept within the GAAR at all. However, apart from fulfilling one of the three statutory alternatives in order to identify abuse, the legal act or some other fact has to lack economic substance. Already from the wording of the clause it is evident that finding "economic substance" is prioritized in order to identify abuse, apart from the cumulative fulfilment of the one of the three above mentioned statutory alternatives. "Searching for" the economic substance of a transaction has a rather long history in our judicial doctrine with respect to the substance over form principle that has been applied in our tax system for a long time. The role of the principle within its meaning was to counteract simulation actions and sham transaction within the tax administration before the adoption of the statutory GAAR. The adoption of the statutory GAAR and a developed ECJ case law on prohibition of abuse rather involved application problems. There is a clear confusion in the contemporary judiciary when it comes to testing the abuse of tax law. Developing case law started to operate not only with finding the objective and subjective element of abuse as it was brought by the ECJ rulings, but also to hold on the finding of economic substance of the transaction. ${ }^{29}$ This might create confusion but on the other hand the substance over form principle is still present in the Tax code. After all, the economic substance may be easily found and proved on the value added tax cases, but it has not been tested on corporate tax avoidance cases from the area of direct taxation by courts yet. The finding of the "real" economic substance in such cases might be in our view much more difficult and the economic substance test might become less reliable. Subsequently, the purpose test as a part of subjective testing (or as a separate additional element of finding abuse) is of significant importance by identifying abusive practices as well.

\subsection{Purpose Test}

Purpose test represents one of the most controversial issues when discussing GAARs. The terminological chaos has already been caused by different "intensity" expressions of testing the purpose of arrangements what has been brought by the ECJ. First of all, the essential purpose had been presented by Halifax as a criterion in identifying abuse. ${ }^{30}$ After that, things became more complicated under Part Service ruling in which more "levels" of purpose were illustrated. ${ }^{31}$ Following the development of ECJ ruling, the expression of the intensity of tested purpose is far from being clear and the ECJ and domestic courts collide amongst many alterations - from the sole purpose, through 
principal purpose, one of the principal purposes up to the essential purpose of the arrangement (transaction).

Purpose test is a part of the EU GAAR brought by the Commission's recommendation on aggressive tax planning. Under the meaning of the EU GAAR, the essential purpose of the arrangement (transaction) is relevant. An attempt to clarify "the essential purpose" is subsequently provided by par. 4.6 of the recommendation, under which "for the purposes of point 4.2, a given purpose is to be considered essential where any other purpose that is or could be attributed to the arrangement or series of arrangements appears most negligible, in view of all the circumstances of the case". In our view, this merely contributes to understanding of what actually the essential purpose is. It only makes the situation more difficult by identifying more purposes, the negligibility and circumstances of which have to be compared. Apart from that, the wording of the clause of EU GAAR is contrary to the ECJ's case law since par. 4.2, mentions an artificial arrangement or an artificial series of arrangements which has been put into place for the essential purpose of avoiding taxation. Consistently with the ECJ's rulings, an essential purpose of arrangement should be manifested by obtaining tax benefit in the first place.

Implementing EU GAAR, the intensity of "purpose testing" had (luckily) not been specified within the wording of the Slovak GAAR. ${ }^{32}$ On the other hand, the explanatory report brings more chaos providing the aim of the new clause which is "to enable tax authorities to disregard within administration, e.g. artificial transactions and structures created for the purpose of an undesired tax optimization, even in a case when such an optimizing is not the sole purpose of the transactions and structures" (what is actually contrary to the wording of the clause). ${ }^{33}$ The wording of the Slovak GAAR rather leaves the door open for tax authorities and courts to interpret and potentially sets limits to the required purpose for abusive arrangements. Purpose test as such is in our view a rather unreliable and questionable criterion that might easily tempt tax authorities and courts to focus on the purpose of the arrangement instead other criteria by identifying abusive practices. ${ }^{34}$

\subsection{Tax Advantage and Legal Consequences}

Tax advantage presents a part of GAAR testing and the EU GAAR provides in this respect under par. 4.7 with a few situations when tax benefit may occur. ${ }^{35} \mathrm{~A}$ demonstrative list of a few situations under which tax benefit occurs is rather promising, suggesting that the idea of the tax benefit is of a broader scope. However, assessment of the situation if arrangement or series of arrangements lead to a tax benefit under par. 4.2 of the recommendation relies on a fiction. ${ }^{36}$ In our view, tax advantage represents the result of the arrangement (transaction) and it is up to the tax authority to prove its obtainment. Nevertheless, the finding and confirming of the objective element and subjective element of abuse should be performed in the first place. Otherwise, the fictitious reconstruction of the arrangement without having any specified discretionary limits might unjustifiably strengthen decisive powers of tax authorities. Once the obtainment of tax benefit is confirmed by the tax authority, the taxpayer fails to prove the opposite. 
When it comes to legal consequences of the application of GAAR, Slovak GAAR corresponds with the EU GAAR which provides that an abusive arrangement (or series of arrangements) shall be ignored. As it is provided by par. 4.2 of the recommendation, national authorities shall treat these arrangements for tax purposes by reference to their economic substance, what brings us back to the substance over form principle applied in our national tax law for decades.

\section{Implementation of Anti-Tax Avoidance Directive GAAR?}

Legislative ambitions of EU law makers of recent years with respect to statutory GAARs have been intensified and manifested by the prompt adoption of Anti-Tax Avoidance Directive (henceforth ATAD). ${ }^{37}$ ATAD GAAR represents in itself the ultimate force to adopt statutory GAAR for those member states who have not entered statutory GAAR in their domestic laws by now. ${ }^{38}$ GAAR incorporated in the art. 6 of Anti-Tax Avoidance Directive ${ }^{39}$ is the measure of "minimum standard" and shall not preclude the application of domestic or agreement-based provisions aimed at safeguarding a higher level of protection for domestic corporate tax bases. ${ }^{40}$ As the preamble of the Directive says, it is important to ensure that the GAARs should be applicable in domestic situations, within the Union and vis-à-vis third countries in a uniform manner, so that their scope and results of application in domestic and cross-border situations do not differ. ${ }^{41}$ It is outside the scope of the article to bring a closer analysis of the issue, however, ATAD GAAR seems like a follower of previous statutory EU GAARs and ECJ's case law and becomes a "codification mixture" of all. ${ }^{42}$ However, the question of application scope makes it different as it was constructed to apply only to corporate taxation. Despite the fact that Slovakia already has GAAR incorporated in its Tax Code, several implementation possibilities could be mentioned. The situation becomes more interesting regarding our tax system compared with member states that lack statutory GAAR in their tax systems (and are obliged to incorporate ATAD GAAR into their domestic tax legislation). As we already have statutory GAAR, the following possibilities could be mentioned:

- incorporation of the ATAD GAAR into the domestic law for all tax purposes with the corresponding repeal of the existing statutory GAAR; or

- implementation of the ATAD GAAR according to the original scope of the Directive and preservation of traditional statutory GAARs for all other taxpayers and tax liabilities; or

- no explicit implementation of the ATAD GAAR in the domestic legislation holding the view that existing GAARs suffice. ${ }^{43}$

It seems likely that none of these three options could be rejected from the very first impression while applying the GAAR concept for the Slovak tax system. However, due to the limited extent of the article the issue of the implementation possibilities of the ATAD GAAR is fully left for another time. 


\section{Conclusion}

The concept of statutory GAARs is currently gaining a remarkable attention in tax systems all around the world. Statutory GAARs at EU level became such phenomena that member states had to deal with in the last years. CEE countries are especially targeted by the implementation of GAARs since the statutory (and often judicial) concept of GAARs had been lacking in their tax systems and (or) is just under development. The case of statutory Slovak GAAR that has been implemented under the Commission's recommendation on aggressive tax planning (EU GAAR) shows that the implementation went rather on its own way and the final wording of the GAAR in the Tax code is rather different from what was requested by the EU GAAR and ECJ's case law at the end of the day. In our view, the main issue of the Slovak GAAR is that it totally gives up on objective testing and attracts its attention to "economic substance" testing what is still not really "clearly" developed by courts and only expresses the nature of the substance over form rule applied by tax authorities and courts for decades before. ${ }^{44}$ The new clause has however not been tested properly by courts, so the interpretation could only be presumed. The abuse of tax law was judicially confirmed in Slovakia only a few years ago under the decision of the Highest Court ${ }^{45}$ issued after answering preliminary ruling by ECJ (Tanoarch). ${ }^{46}$ After that, the way of the identification of abuse of tax law by courts is not consistent relying on objective and subjective testing on the one hand, and finding of the economic substance on the another one. Nevertheless, it is, in our view, just the beginning of the journey in which statutory GAARs will play a more important role. However, for next time the way of the implementation should not be underestimated. 


\section{References}

1. This paper was written as a partial output of the research project APVV-16-0160: "Tax evasions and tax avoidance (motivation factors, formation and elimination)", as well as the output of the project VEGA 1/0846/17: "Implementation of the initiatives of the EU institutions in the field of direct taxes and indirect taxes and their budgetary law implications".

2. Rita de la Feria, Prohibition of Abuse of (Community) Law - The Creation of a New General Principle of EC Law Through Tax?, 395 et seq., in Common Market Law Review, vol. 45 (2008). https://doi.org/10.2139/ssrn.3475123

3. Wolfgang Schön, Abuse of Rights and European Tax Law, 78 et seq., in Comparative Perspectives on Revenue Law (Cambridge, University Press, 2008). https://doi.org/10.1017/CBO9780511585951.006

4. Starting with the first Common Consolidated Corporate Tax Base (henceforth CCCTB) proposal GAAR, followed by a GAAR in financial transaction tax proposal, by the "EU GAAR" represented by the Commission's recommendation on aggressive tax planning, as well as GAARs in direct tax directives, leading subsequently to the last resort - Anti-Tax Avoidance Directive GAAR.

5. For more information see: Anna Románová, The New Anti Abuse Rule in Slovak Tax Law: Strengthening of the Legal Certainty?, 214, in System of Financial Law (System of Tax Law) (Brno, Masaryk University, 2015). Similarly: Anna Románová, Karolína Červená, Nová úprava zásady skutočného obsahu právneho úkonu v Daňovom poriadku [The New Regulation of the Principle of Material Content of Legal Act in the Tax Ordinance], 198 et seq., in Marketing, manažment, obchod a sociálne aspekty podnikania: zbornik recenzovaných príspevkov z 2. ročnika medzinárodnej vedeckej konferencie: 23-24 október 2014, Košice [Marketing, Management, Business and Social Aspects of Enterprises: Reviewed Book of Proceedings from the 2. Season of International Scientific Conference: Košice, 2017 October 23-24] (Košice, Ekonomická Univerzita v Bratislave - Podnikovohospodárska fakulta so sídlom v Košiciach, 2014). Similarly: Miroslav Štrkolec, Fighting Tax Evasion and its Reflection in the Procedural Tax Law, 468 et seq., in Tax Codes Concepts in the Countries of Central and Eastern Europe. Similarly: Vladimír Babčák, Daňové právo na Slovensku [Tax Law in Slovakia], 439 et seq., (Bratislava: EPOS, 2015). As well as: Mária Bujnáková, [Fundamentals and Principles of Tax Proceedings], 11, in Zeszyty Naukowe Universytetu Rzeszowskiego: seria prawnicza [Scientific Writings of the University of Rzeszow: Law Series] vol. 91, no. 18 (2016).

6. See more: Markus Seiler, GAARs and Judicial Anti-Avoidance in Germany, the UK and the EU, 145 et seq., (Vienna, Linde, 2016).

7. $\mathrm{C}-110 / 99$.

8. C $-255 / 02$.

9. C $-196 / 04$.

10. According to paragraphs 52 and 53 of Emsland-Stärke ruling, "a finding of an abuse requires, first, a combination of objective circumstances in which, despite formal observance of the conditions laid down by the Community rules, the purpose of those rules has not been achieved. It requires, second, a subjective element consisting in the intention to obtain an advantage from the Community rules by creating artificially the conditions laid down for obtaining it".

11. Under Cadbury Schweppes ruling (55 et seq.), restriction of freedom of establishment might be justified only when it is aimed at the preventing of the creation of wholly artificial arrangements intended to escape the national tax normally payable.

12. Par. 4.2 of recommendation, available under http://eur-lex.europa.eu/legal-content/EN/TXT/HTML/? uri=CELEX:32012H0772\&from=EN (accessed 20 June 2017).

13. A principle explicitly incorporated in the provision of $₫ 3 \mathrm{p} .1$ of the Tax code that directly stresses that an actual content of the legal action (transaction) over the form should be preferred. See more: Karin Prievozníková, Implementácia zákazu zneužitia práva do daňového poriadku [Implementation of the Prohibition of Abuse of Rights in the Tax Ordinance], 161 et seq., in Daňové právo vs. dañové podvody a daňové úniky: nekonferenčný zbornik vedeckých prác. II. diel [Tax Law vs. Tax Fraud and Tax Evasion: Non-conference Book of Scientific Work. II. part.], (Košice, Univerzita Pavla Jozefa Šafárika v Košiciach, 2015). Also see: Anna Románová, Karolína Červená, Nová úprava zásady skutočného obsahu právneho 
úkonu v daňovom poriadku [The New Regulation of the Principle of Material Content of Legal Act in the Tax Ordinance], 189 et seq., in Marketing, manažment, obchod a sociálne aspekty podnikania: zbornik recenzovaných prispevkov z 2. ročnika medzinárodnej vedeckej konferencie: 23-24 október 2014, Košice [Marketing, Management, Business and Social Aspects of Enterprises: Reviewed Book of Proceedings from the 2. Season of International Scientific Conference: Košice, 2014 October 23-24] (Košice, Ekonomická Univerzita v Bratislave - Podnikovohospodárska fakulta so sídlom v Košiciach, 2014).

14. Par. 1 defining subject matter and the scope of the recommendation.

15. Similarly: Lubica Adame, GAAR in Slovakia, 585, in GAARs - A Key Element of Tax Systems in the Post BEPS World (Amsterdam, IBFD, 2016).

16. Such as local fee for municipal waste and minor construction waste and local fee for development under the law no. 582/2004 Coll. Concerning the issue of the local fee see more: Ivana Štieberová, Local Fee for Municipal Waste and Minor Construction Waste in the Light of Legislative Changes, 405 et seq., in Local Government Financing and European Charter of Local Self-Government (Warszawa, CeDeWu, 2016). Concerning the issue of the other fee see as well: Adrián Popovič, Reflection on the Local Fee for Development, 57 et seq., in Local Government Financing and European Charter of Local Self-Government (Warszawa, CeDeWu, 2016) and Adrián Popovič: Zamyslenie sa nad miestnym poplatkom za rozvoj [Thoughts on Local Fee on Development], 1263 et seq., in Justičná revue, vol. 68, n.11 (2016).

17. C $-110 / 99$, p. 52.

18. C $-255 / 02$, p. 74 .

19. C - 196/04, p. 64.

20. Markus Seiler, GAARs and Judicial Anti-Avoidance in Germany, the UK and the EU, 183 et seq. (Vienna, Linde, 2016).

21. Explanatory report to the law proposal no. $435 / 2013$ Coll. amending the law no. $563 / 2009$ Z. z. on administration of taxes. Available online https://www.nrsr.sk/web/Default.aspx?sid=zakony / zakon\&MasterID=4553 (accessed 20 June 2017).

22. Similarly: Anna Románová, The New Anti Abuse Rule in Slovak Tax Law: Strengthening of the Legal Certainty?, 214 et seq., in System of Financial Law (System of Tax Law) (Brno, Masaryk university, 2015).

23. Par. 4.7 of the recommendation.

24. As it was provided in opinions of general advocate Maduro in par. 71 of Halifax judgement: "It is the consideration of the objective purpose of the Community rules and of the activities carried out, and not the subjective intentions of individuals, which, in my view, lies at the heart of the Community law doctrine of abuse".

25. Par. 53 of C - 110/99, par. 75 of C $-255 / 02$, par. 64 of C - 196/04.

26. Par. 55 of $\mathrm{C}-196 / 04$.

27. After that, in determining whether the arrangement or series of arrangements is artificial, national authorities are invited to consider whether the y involve one or more of the situations as provided by the par. 4.4 of the recommendation.

28. Seiler, supra n. 20, 204. Similarly: T. Lyons, The Financial Crisis, Tax Avoidance and an EU GAAR, 114, in British Tax Review, no. 2 (2013).

29. The identification of the absence of the economic substance had been present in the judgment of the Highest court of Slovak Republic no. 3 Sžf/45/2010 from 2 June 2011.The case dealt with the simple fictitious VAT transactions, where the actual content of transaction has not been found contrary to the formal declarations in order to obtain VAT returns.

30. Par. 75 of C $-255 / 02$. Purpose test has not been specified in Emsland-Stärke ruling at all.

31. Under par. 40 of C $-425 / 06$ a following reference had been made to the court: "...whether the Sixth Directive should be interpreted as meaning that there can be a finding of an abusive practice when the accrual of a tax advantage is the principal aim of the transaction or the transactions in question, or if such a finding can only be made if the accrual of that tax advantage constitutes the sole aim pursued, to the exclusion of other economic objectives. 
32. The clause provides with its wording only purpose-built tax avoidance and purpose-built reduction of $\operatorname{tax}$ liability (by obtaining tax benefit it is rather evident that the purpose has to be present).

33. See more: Románová, supra n. 22, at 218.

34. Similarly: Seiler, supra n. 20, 212.

35. Under par. 4.7 of the recommendation following situations are mentioned:
a) an amount is not included in the tax base,
b) the taxpayer benefits from the deduction,
c) a loss for tax purposes is incurred,
d) no withholding tax is due,
e) foreign tax is offset.

36. National authorities are invited to compare the amount of tax due by a taxpayer, having regard to those arrangement(s), with the amount that the same taxpayer would owe under the same circumstances in the absence of the arrangement(s).

37. Council Directive (EU) 2016/1164 of 12 July 2016 laying down rules against tax avoidance practices that directly affect the functioning of the internal market. Adoption of the directive represents one of the measures that have been introduced by the European Commission on 28 January 2016 as a part of "Anti-Tax Avoidance Package".

38. For example in the case of the Czech Republic or Croatia.

39. The wording of the ATAD GAAR is the following: "For the purposes of calculating the corporate tax liability, a Member State shall ignore an arrangement or a series of arrangements which, having been put into place for the main purpose or one of the main purposes of obtaining a tax advantage that defeats the object or purpose of the applicable tax law, are not genuine having regard to all relevant facts and circumstances. An arrangement may comprise more than one step or part."

40. Art. 3 of Directive. See more: Luc De Broe \& Dorien Beckers, The General Anti Abuse Rule of the AntiTax Avoidance Directive: An Analysis Against the Wider Perspective of the European Court of Justice's Case Law on Abuse of EU Law, 141, in EC Tax Review, no. 3 (2017).

41. P. 11 of the preamble to the Directive.

42. Similarly: Broe \& Beckers supra n. 40, at 139.

43. Andrés Báez Moreno, A pan-European GAAR? Some (un)expected consequences of the proposed EU Tax Avoidance Directive combined with the Dzodzi line of cases, 143 et seq., in British Tax Review, no. 2 (2016).

44. Karin Prievozníková, Implementácia zákazu zneužitia práva do daňového poriadku [Implementation of the Prohibition of Abuse of Rights in the Tax Ordinance], 168, in Dañové právo vs. dañové podvody a dañové úniky: nekonferenčný zborník vedeckých prác. II. diel [Tax Law vs. Tax Fraud and Tax Evasion: Non-conference Book of Scientific Work. II. part.] (Košice, Univerzita Pavla Jozefa Šafárika v Košiciach, 2015). Similarly: Ivana Forraiová, Právne dôsledky zneužívania daňovo-právnych noriem [Legal Consequences of Abusing Tax-Law Norms], 86 et seq., in Zneužitie a iné formy obchádzania práva [Abuse and Other Forms of Law Avoidance] (Košice, UPJŠ, 2016). Similarly: Ivana Štieberová, Zneuživanie práva pri uplatňovaní nadmerných odpočtov dane z pridanej hodnoty [Abuse of Law in the Application of Excess VAT Deductions] 305 et seq., in Zneužitie a iné formy obchádzania práva [Abuse and Other Forms of Law Avoidance] (Košice, UPJŠ, 2016).

45. Judgment no. 5 Sžf/66/2011. See more: Peter Huba, Jozef Sábo \& Miroslav Štrkolec, Medzinárodné daňové úniky a metódy ich predchádzania [International Tax Avoidance and Methods of The ir Prevention], 146, (Košice, UPJŠ, 2016).

46. C - 504/10 Tanoarch. 